\title{
Development of Interactive Media to Improve Early Childhood Financial Literacy
}

\author{
$1^{\text {st }}$ Srinahyanti ${ }^{1}, 2^{\text {nd }}$ Dorlince Simatupang ${ }^{2}, 3^{\text {rd }}$ Suri Handayani Damanik ${ }^{3}$ \\ \{sher@unimed.ac.id ${ }^{1}$ \} \\ Early Childhood Teacher Education Department, Faculty of Education, Universitas Negeri Medan 1,2,3
}

\begin{abstract}
This study aims to describe the process of developing interactive media. In particular, this study aims to produce its to improve early childhood financial literacy. This study uses the ADDIE development model consisting of 5 main stages : (1) Analysis, (2) Design, (3) Develop and (4) Implement and (5) Evaluate. Data analysis techniques through stages; First, analysis of validity through the average score of the developed media aspects. Second, if each category is valid, then proceed to the analysis of the effectiveness of the product through the analysis of media practicality questionnaire data by teachers and early childhood. Validation by media and materials experts to determine the success of media design. Based on the results of the validity test questionnaire for interactive media development, it can be said that the media is categorized as valid with a validity percentage of $84 \%$, this interactive media as whole has a good validity.
\end{abstract}

Keywords: Interactive media, childhood financial literacy.

\section{Introduction}

Human success today is influenced by 21 st-century abilities or skills [4]. states that to face the 21st century, humans must master six literacies at least. One of them is financial literacy. Financial literacy is a form of knowledge and public awareness of financial management. This ability is a must because it contributes to the economy's growth, and it is owned and cultivated in early childhood [6]. The early recognition will create habits in children to manage their finances properly, correctly in the future. Financial literacy is not just understanding concepts, but also the process is in the ability to analyze needs and priorities, children can make simple and wiser financial decisions and apply them in everyday life. Financial literacy is showing by attitudes and behavior.

The level of Understanding and financial management skills affect the degree of wellbeing [12]. The Consumer Financial Protection Bureau said that most schools do not teach children to manage their finances, so many children have low financial literacy and causing the problem of poverty. In support of the above statement, the results of the Financial Health Index of five Asia Pacific Countries conducted by GoBear, a fintech startup operating in Singapore, show. The highest literacy score is Singapore with $79 \%$, followed by Hong Kong with $72 \%$, the Philippines with 71, Thailand with 68\%, and Indonesia with 67\% [1]. The index is linearly proportional to the level of welfare of the country. Singapore ranks 0.91 , Thailand 0.72 , Indonesia 0.68 [1]. 
Financial literacy can make effective policies about how they live now and in the future, improve their finances, social welfare, can participate in society. Education on financial management will be effective carried out from an early age on an ongoing basis becomes an attitude and behavior and children's culture.

Education about financial literacy in children through various media, one of which is interactive media. Interactive media is a digital service product on computer-based systems that present text, images, and sounds that respond to user actions. Interactive media can provide meaningful experiences because its features facilitate the development of sensor and motoric of children.

Based on the above explanation, researchers are attracted to developing interactive media based on financial literacy that corresponds to the needs of children of an early age, the target characteristics. It should be able to improve learning activities and problem-solving skills. The media expected to improve children's attitudes in use and manage financesThe first paragraph after a heading is not indented.

\section{Methods}

The research that will be conducted is development research. Research and development $(\mathrm{R} \& \mathrm{D})$ is a research method used to produce certain products and test the effectiveness of these products [8]. Development research is a systematic study of the design, development and evaluation of programs, processes and products that must meet the criteria of validity, practicality and effectiveness. The type of development in this study will use ADDIE model suggested. The development model in this study uses the ADDIE development model because this model is used to develop multimedia or media. The sequence of steps in this model is very systematic. This model consists of 4 stages of development, Analiyz, Design, Develop, Implementation, Evaluate.

The Data acquired through data documents to find out important needed in media development, interviews using interview guidelines, validation questionnaires for experts or expert judgment and observation instruments.

There are two stages to analyze data; First, validity analysis. Content validity through interactive media experts using a construct validity approach. Validity analysis through the average score on aspects of teaching materials developed with the formula [12]:

$$
R=\frac{\sum_{i=1}^{n} V_{i}}{n}
$$

Keterangan:

$\mathrm{R} \quad=$ the average assessment result

$\mathrm{Vi}=$ the score of the-i validator assestment result

$\mathrm{n} \quad=$ number validators. 


\section{Results \& Discussion}

\subsection{Analyzing Stage}

At this stage, the researcher identifies what material will be burst out through interactive media, then adjust according to the achievement of development or the characteristics of children.

Feasibility analysis and product development requirements through several questions; (1) Can the media overcome the variables you want to study? (2) Is the media supported by the facility, (3) Can the product be used by teachers/parents or children?

Based on observations at school, Knowledge money and usage are rare even though they can cultivate an engaging theme. It can also be part of a theme that comes from incidental. The discussion result with PAUD teachers revealed that concept recognition of money and financial management implemented through ask activities and the habit of saving. Based on these initial observations, teaching materials in the form of interactive media are needed to increase children's understanding and awareness of finance

Furthermore, The researcher observes a potential user of interactive media. The target users of this interactive media are early childhood aged 5-6 years.

The next step is to analyze the material to expand in the media. The level of breadth and depth of the material refers to the Standard for Achievement of Early Childhood Development as stated in Permendikbud 137 of 2014. After describing the Core Competencies according to the 2013 Curriculum, the next step is to describe the base competencies. Basic Competence is the level of ability in the context of learning content, learning themes, and learning experiences that refer to Core Competencies.

The formulation of Basic Competencies is developed by taking into account the characteristics and initial abilities of children as well as the objectives of each development program.

Based on the description of the base competencies of each core competency in the 2013 PAUD Curriculum. Although this teaching material focuses on early childhood financial material, the content still pays attention to the core competenies of spiritual, social attitudes, knowledge, and skills outlined in the basic competencies mentioned above. The description is manifested in the part of the teaching materials developed, namely the part of playing activities on interactive media

Analysis of learning objectives is carried out to determine indicators of learning achievement based on material analysis and curriculum analysis. Learning objectives are written so that researchers can find out what materials and activities to display in the media.

Achievement indicators are determined through an analysis of learning objectives based on an analysis of the material and curriculum. By writing the learning objectives, researchers can find out what materials and activities will be displayed in the teaching materials.

\subsection{Designing Stage}

The stage aims to design a prototype learning device. Design activities in the ADDIE development research model are a systematic process that starts from designing concepts and content in the media. Concept and content design in storyboards/flowcharts, then interactive media developed using Microsoft PowerPoint Software with several frames.

\subsubsection{Opening frame (Cover)}




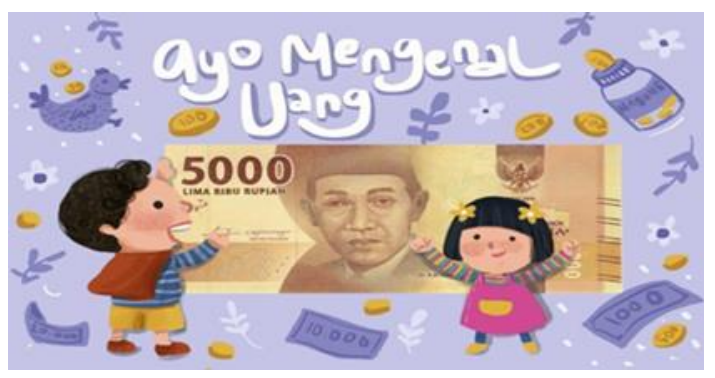

Fig. 1. Learning resource variations.

\subsubsection{Homepage Frame}

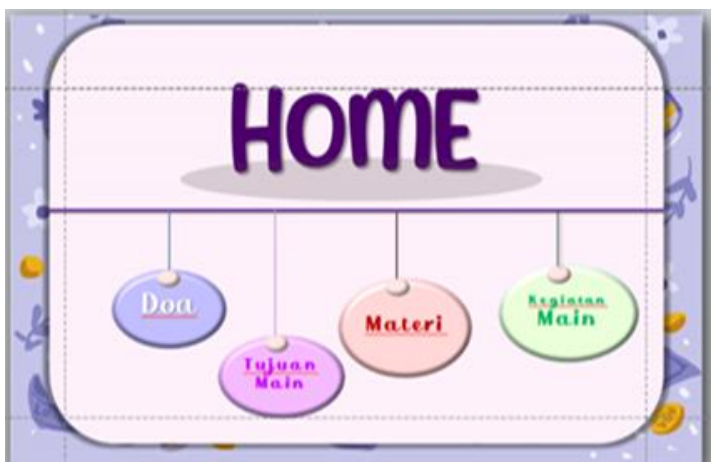

Fig. 2. Home page frame.

3.2.3 Activity Frame. Activity Frame developed from financial literacy indicators

a) Children's ability to define money

b) Children's ability to classify types of money based on their shape and material

c) The ability to conclude the use of money

d) The use of money in daily activities

e) Children's ability to use money according to its function

f) the child's ability to select needs and desires

g) show an attitude of saving money 


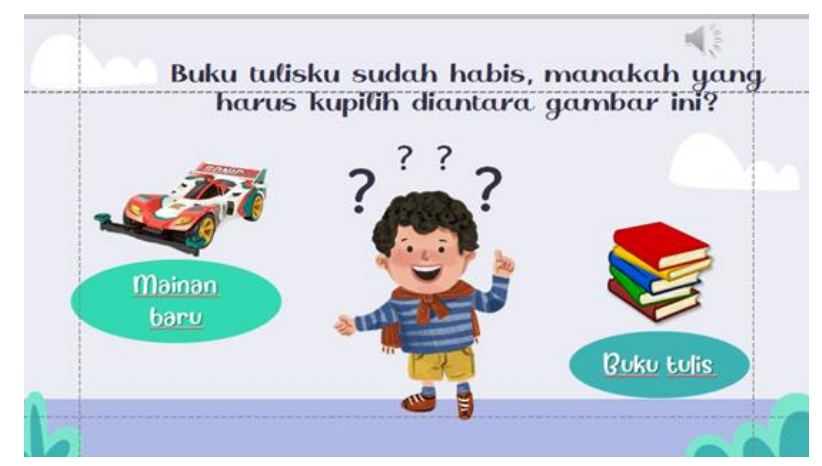

Fig. 3. One of the activity frame.

The development stage aims to revise the media through expert input regarding the content/material of an interactive media, namely through the validation process of developing interactive media to improve financial intelligence. The instrument is filled out in by the validator, namely Mrs. Wan Nova Listia, S.Pd., M.Pd. from the Faculty of Education, who is an expert in the field of PAUD, and Mrs. Revita Yuni, S.Pd., M.Pd. from the Faculty of Economics who is an expert in the field of Economics and finance.

Based on the results of the validity test questionnaire for Interactive Media Development, it can be said that the media is categorized as valid with a validity percentage of $84 \%$.

The average percentage of content aspects $(83 \%)$ means that the material is appropriate with Indicators and user needs. The material is supported by relevant financial theory, the presentation of the material is accurate, coherent, and following existing facts and concepts.

The average percentage of media from the aspect of presentation feasibility is around $85 \%$. Feasibility of presentation concerning the systematic presentation in every learning activity. The presentation is interactive and participatory (there is a section that invites the child to participate). The material is supported by pictures and factual illustrations

The percentage seen from the linguistic aspect, teaching materials revisions regarding the use of language in this media so that the level of validity is around $80 \%$.

The percentage of Media Graph meaning that the use meaning that the use of graphics Background/Layout setting, typography, navigation usage were still categorized as very good were still categorized as very good. The greatest value in this aspect is in the choice of cover and media theme/background color.

\section{Conclusion}

Based on the results, the conclusions are: The value of media validity is $84 \%$ which means that the media is suitable for use in learning activities in PAUD; An analyzing learning objective is necessary to determine the right indicators in developing material for activities in the media, and the design of Interactive media has been carried out and continued on product testing.

Acknowledgments. First and foremost, praise and thanks to ALLAH SWT for blessing in completing the research. I am highly indebted to Universitas Negeri Medan for support and 
funding of this research. My thanks and appreciation also go to people who have willingly helped me out with their ability. This research was supported by the DIPA Fund of the Universitas Negeri Medan for the 2021 Fiscal Year, in accordance with the Unimed Chancellor's Decree No. 124/UN.33.8/KEP/PPKM/2021.

\section{Reference}

[1] Annisa. The Go Bear. Available from https://www.gobear.com/id/blog/personal-finance/yuk-cekskor-literas-keuangan-indonesi-di-2020. [Accessed 28 ${ }^{\text {th }}$ Sept 2020].

[2] Badan Pengembangan dan Pembinaan Bahasa. KBBI Daring. Retrieved from KBBI Daring; 2016.

[3] Dewayan S, Budihardja J, Natakusumah, Y. Menumbuhkan Kecakapan Literasi Keuangan pada Anak Usia Dini. Jakarta: Otoritas Jasa Keuangan Departemen Literasi dan Inklusi Keuangan; 2020.

[4] GLN. Pentingnya Pengenalan Literasi Keuangan Sejak PAUD. Available Available from https://gln.kemendikbud.go.id/glnsite/pentingnya-pengenalan-literasi-keuangan-sejak-paud. from Gerakan Literasi Nasional; 2018.

[5] Hadad MD. Peraturan Otoritas Jasa Keuangan Nomor 76/PJOK.07/2016 tentang Peningkatan Literasi dan Inklusi Keuangan di Sektor Jasa Keuangan Bagi Konsumen dan/atau Masyarakat. Jakarta, Jakarta, Indonesia: Kementerian Hukum dan Hak Asasi Manusia Republik Indonesia; 2016.

[6] Kemendikbud. Pentingnya Pengenalan Literasi Keuangan Sejak PAUD. Retrieved Februari 28, 2021, from Anggun PAUD Kemendikbud: https://anggunpaud.kemendikbud.go id/indexphp/20180525081527/Pentingnya-Pengenalan-Literasi-Keuangan-Sejak-Paud; 2018.

[7] Kurniawan D, Dewi VS. Pengembangan Perangkat Pembelajaran dengan Media Screencast-OMatic Mata Kulia Kalkulus menggunakan Model 4D THIAGARAJAN. Jurnal Siliwangi. 2017; 214-219

[8] Sugiono. Metodologi Penelitian Kuantitatif, Kualitatif, dan R\&D. Bandung: Alfabeta; 2013.

[9] Titik UUS. Analisis Tingkat Literasi Keuangan Mahasiswa Fakultas Ekonomi Universitas Yogyakarta Tahun ANGKATAN 2012-2014. Pelita. 2016; 1-13

[10] Seefeldt, Carol et al. Social Studies for The Preschool/Primary Child. $8^{\text {th }}$ Edition. New York: Pearson; 2010.

[11] UNESCO. UNESCO, Digital Library. Retrieved from UNESCO, Digital Library:; 2003.

[12] Wardianti Y. Validitas Modul Biologi Berbasis Kearifan Lokal; 2018. 